\title{
PENINGKATAN KAPASITAS PRODUKSI IKAN MELALUI PENERAPAN MANAJEMEN KUALITAS AIR DAN PROBIOTIK DI KELOMPOK RAJA OLING KECAMATAN SUKUN KOTA MALANG
}

\author{
INCREASING FISH PRODUCTION CAPACITY THROUGH GOOD WATER QUALITY \\ MANAGEMENT AND PROBIOTIC USAGE IN RAJA OLING GROUP OF MALANG CITY
}

\author{
Ganjar Adhywirwan Sutarjo ${ }^{1 *}$, Rahmad Pulung Sudibyo² \\ ${ }^{1}$ Jurusan Perikanan, Universitas Muhammadiyah Malang \\ 2 Jurusan Agribisnis, Universitas Malang \\ Jalan Raya Tlogomas 246, Kota Malang, Provinsi Jawa Timur \\ ${ }^{*}$ Alamat Korespondensi : ganjar@umm.ac.id
}

(Tanggal Submission: 24 February 2020, Tanggal Accepted: 23 April 2020)

\begin{abstract}
ABSTRAK
Sektor perikanan merupakan salah satu sektor utama dalam mewujudkan ketahanan pangan nasional, namun upaya pengembangan potensi perikanan budidaya khususnya perikanan budidaya air tawar memiliki tantangan dalam pengelolaannya diantaranya adalah menurunnya mutu lingkungan akibat pencemaran, semakin meningkatnya harga pakan buatan pabrik, dan tingginya serangan penyakit yang di sebabkan oleh belum tepatnya penerapan sistem budidaya ikan. Kondisi tersebut, perlu mendapatkan perhatian salah satunya melalui program pengabdian masyarakat internal (PPMI) yang dilaksankan oleh tim perikanan Universitas Muhammadiyah Malang bersama mitra kelompok pembudidaya ikan "Raja Oling". Tujuan dari program PPMI adalah untuk meningkatkan ketrampilan dan pengetahuan mitra terkait cara budidaya ikan yang baik (CBIB), meningkatkan kemampuan Mitra dalam menerapkan manajemen kualitas air melalui penerapan biofilter tanaman air dan pengelolaan mutu air secara berkala, serta meningkatkan ketrampilan dan pengetahuan mitra dalam penggunaan dan perbanyakan probiotik berbasis bahan baku lokal. Kegiatan ini dilaksanakan selama 1 tahun, bertempat di masyarakat pembudidaya ikan yang tergabung dalam kelompok "Raja Oling" di Kelurahan Gadang Kecamatan Sukun Kota Malang. Metode program yang digunakan adalah melalui pelatihan dan pendampingan peningkatan ketrampilan dan pengetahuan mitra tentang cara budidaya ikan yang baik dan ramah lingkungan. pelatihan dan pendampingan teknik pengelolaan kualitas air budidaya ikan air tawar, serta meningkatkan keterampilan mitra terkait teknik perbanyakan probiotik berbasis bahan baku lokal. Hasil kegiatan pelatihan dan pendampingan penerapan manajemen kualitas air pada kegiatan budidaya ikan lele, manajemen budidaya ikan dan konstruksi kolam, dan proses pembuatan pakan ikan mandiri dan perbanyakan probiotik berbasis bahan baku lokal dapat diterima sangat baik, dan berdasarkan evaluasi dapat meningkatkan kapasitas produksi sekaligus perbaikan sistem budidaya ikan di kelompok tani Raja Oling.
\end{abstract}

Kata kunci : Manajemen Kualitas Air, Probiotik dan CBIB 


\section{PENDAHULUAN}

Upaya pengembangan potensi perikanan budidaya khususnya perikanan budidaya air tawar memiliki tantangan dalam pengelolaannya diantaranya adalah menurunnya mutu lingkungan akibat pencemaran, semakin meningkatnya harga pakan buatan pabrik, dan tingginya serangan penyakit akibat belum tempatnya pengelolaan kegiatan budidaya ikan. Kondisi tersebut, perlu mendapatkan perhatian sekaligus upaya penyelesaian dalam rangka meningkatkan kapasitas produksi budidaya ikan air tawar.

Salah satu wilayah pengembangan kegiatan budidaya ikan air tawar di Kota Malang adalah kelurahan Gadang. Secara geografis Kelurahan Gadang berada pada ketinggian 440 m $460 \mathrm{~m}$ di atas permukaan air laut, topografi wilayah berupa dataran. Terdapat beberapa kelompok tani dan kelompok pembudidaya ikan salah satunya adalah kelompok pembudidaya ikan "Raja Oling", kelompok pembudidaya ikan ini yang terbentuk pada tahun 2014, dengan ketua bapak Aripin dan jumlah anggota kelompok sebanyak 20 orang, dengan rata-rata kepemilikan kolam sebanyak 11 unit, luas masing - masing kolam $12 \mathrm{~m} 2-48 \mathrm{~m} 2$. Komoditas perikanan air tawar yang saat ini dikembangkan adalah ikan Lele dumbo, ikan Nila, dan ikan Gurame. Kontruksi kolam budidaya ikan masih berupa kolam tanah, dan kolam terpal. Sumber air berasal dari sumur bor, dan saluran irigasi. Rata-rata tingkat pendidikan anggota kelompok adalah lulusan sekolah menengah atas (SMA).

Informasi yang diperoleh dari ketua dan anggota, kendala yang dihadapi dalam kegiatan budidaya ikan air tawar kelompok pembudidaya ikan "Raja Oling" adalah masih kurangnya informasi dan pendampingan proses budidaya ikan yang baik. Saat ini, sistem budidaya ikan yang digunakan adalah sistem atau cara budidaya ikan secara tradisional, suplay air mengandalkan sumur bor dan saluran irigasi, namun pada penggunaan saluran irigasi tingginya buangan limbah industri menyebabkan mutu air menurun. Kendala lain dengan semakin meningkatnya harga pakan buatan pabrik yang mencapai $10.700 / \mathrm{kg}$. berdampak pada semakin besarnya biaya produksi yang dikeluarkan oleh mitra sebab pakan ikan merupakan komponen biaya terbesar mencapai \pm $60 \%$ dari total biaya produksi ikan.

Berdasarkan hal tersebut, pembudidaya ikan air tawar yang tergabung dalam kelompok pembudidaya ikan Raja Oling, sangat mengharapkan adanya pendekatan teknologi tepat guna yang mudah dalam penerapannya, dan mampu diterapkan secara berkelanjutan. Teknologi tersebut diantaranya adalah penerapan teknologi manajemen kualitas air melalui penggunaan biofiltasi tanaman air dan penyaringan bertahap, penerapan sistem budidaya ikan yang baik (CBIB) sehingga kualitas sistem budidaya dapat diperbaiki, serta penerapan probiotik melalui media air. Sehingga melalui kegiatan ini diharapkan mampu memberikan pengaruh positif bagi peningkatan kesejahteraan ekonomi masyarakat pembudidaya ikan air tawar di kelurahan Gadang kecamatan Sukun kota Malang.

\section{Tujuan Kegiatan}

Kegiatan pengabdian ini bertujuan untuk meningkatkan ketrampilan dan pengetahuan mitra terkait cara budidaya ikan yang baik (CBIB), meningkatkan kemampuan Mitra dalam menerapkan manajemen kualitas air melalui penerapan biofilter tanaman air dan pengelolaan mutu air secara berkala, serta meningkatkan ketrampilan dan pengetahuan mitra dalam penggunaan dan perbanyakan probiotik berbasis bahan baku lokal

\section{Manfaat Kegiatan}

Kegiatan pengabdian masyarakat internal di kelompok pembudidaya ikan "Raja Oling" Kelurahan Gadang Kecamatan Sukun Kota Malang dapat memberikan manfaat sebagai berikut yaitu mitra program dapat menerapkan model budidaya ikan yang baik (CBIB) dalam kolam terpal, memahami kebutuhan dan fungsi prasarana dan sarana produksi budidaya, mitra mampu menerapkan teknik manajemen kualitas air melalui penggunaan filter biologi atau biofiltering, mitra mampu memproduksi atau memperbanyak probiotik secara mandiri. 


\section{METODE PELAKSANAAN}

Metode yang digunakan dalam pelaksanaan program pengabdian masyarakat internal ini adalah memberikan solusi dan informasi dasar terkait cara budidaya ikan yang baik (CBIB), pengelolaan atau manajemen kualitas air, penggunaan dan perbanyakan probiotik berbasis bahan lokal di kelompok pembudidaya ikan "Raja Oling" Kelurahan Gadang Kecamatan Sukun Kota Malang yang diterapkan melalui kegiatan pelatihan dan pendampingan disertai model budidaya ikan air tawar dikolam terpal.

Tahapan dalam menyelesaikan permasalahan yang terdapat pada Kelompok pembudidaya ikan Raja Oling adalah sebagai berikut yaitu:

1. Menerapkan metode ceramah melalui pelatihan, dan pendampingan secara teoritis maupun praktis pada khalayak sasaran atau mitra.

2. Melaksanakan pendampingan pada pembudidaya ikan tentang manajemen kolam budidaya ikan dan manajemen kualitas air.

3. Penerapan teknologi pembuatan probiotik secara mandiri, penanggulangan hama dan penyakit ikan melalui pengelolaan kualitas air, dan pembuatan pakan ikan alternatif.

4. Melakukan sosialisasi pada masyarakat pembudidaya ikan setempat agar masyarakat mengetahui proses pembuatan probiotik, langkah-langkah penanggulangan penyakit melalui pengelolaan kualitas air lingkungan secara berkesinambungan, serta pembuatan pakan ikan alternatif.

5. Melakukan evaluasi secara keseluruhan tentang keberhasilan program baik secara fisik maupun respon khalayak sasaran atau mitra dan masyarakat setempat.

\section{HASIL DAN PEMBAHASAN}

Program Pengabdian Masyarakat Internal (PPMI) dilaksanakan selama 1 Tahun di kelompok pembudidaya ikan "Raja Oling” Kelurahan Gadang Kecamatan Sukun Kota Malang yang diterapkan melalui kegiatan pelatihan dan pendampingan disertai model percontohan budidaya ikan air tawar dikolam terpal. Adapun kegiatan yang telah dilakukan dalam pelaksanaan program PPMI Skim Kelompok adalah sebagai berikut:

\section{Pelatihan Manajemen Kualitas Air dan Penerapan} Probiotik di Kelompok Tani "Raja Oling"

Materi pelatihan secara umum menitik beratkan pada aspek pengelolaan atau manajemen kualitas air dan penerapan probiotik yang sesuai kebutuhan ikan yang dibudidayakan. Pengelolaan kualitas air memegang peranan penting dalam kegiatan budidaya ikan, pengaruh dari pengelolaan kualitas air yang kurang tepat dapat mengakibatkan timbulnya permasalahan yaitu meningkatnya serangan penyakit dan parasit ikan yang dapat menyebabkan kegagalan panen. Menurut Sutarjo, dan Warkoyo (2019) menyatakan bahwa manajemen atau pengelolaan kualitas air memegang peranan penting dalam kegiatan budidaya ikan, yang kegiatan meliputi pengontrolan kolam terpal, pemasangan instalasi aerasi, serta pengukuran kualitas air dengan menggunakan alat thermometer suhu air, oxymeter untuk mengukur kandungan oksigen terlarut dalam air, dan $\mathrm{pH}$ test untuk mengukur kadar $\mathrm{pH}$ air. Melalui kegiatan ini pengukuran kualitas air secara kontinyu maka mutu kualitas air bagi kegiatan budidaya dapat terus terkendali, dan layak bagi kegiatan pembenihan dan pembesaran ikan.

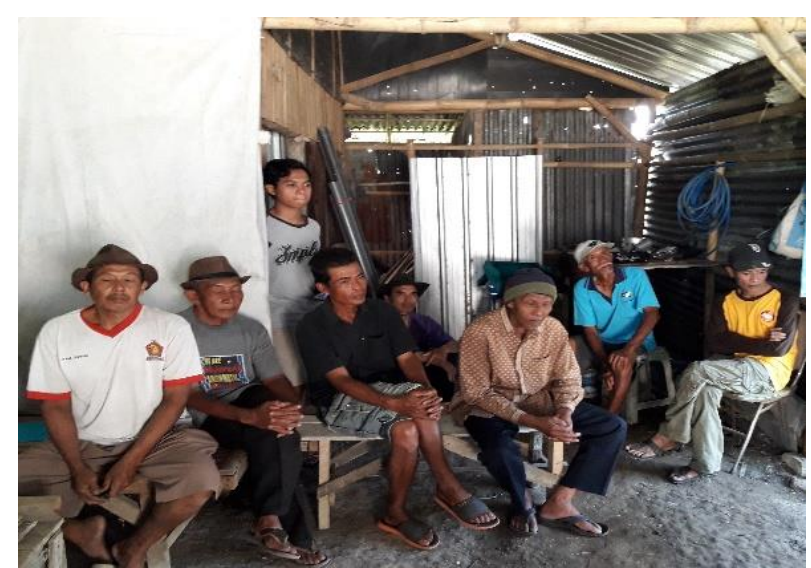

Gambar 1. Pelatihan Manajemen kualitas air, dan Penerapan Probiotik.

Langkah selanjutnya memberikan pentunjuk praktis dosis penggunaan bahan kimia dalam pengelolaan kualitas air yaitu penggunaan antibiotik herbal yang berbasis pada bahan baku 
lokal yang tersedia diwilayah mitra diantaranya temu lawak, buah mengkudu, dan daun pepaya. Selain hal tersebut, upaya melakukan perbaikan mutu kualitas air dengan mengoptimalkan fungsi filter fisik yaitu peran zeolit, karbon aktif, dan filter pasir, untuk menguraikan unsur amoniak, nitrat, dan phospat. Menurut Samsundari (2006) menyatakan bahwa Hasil uji cakram menunjukkan adanya pengaruh nyata dari perlakuan ekstrak kunyit maupun ekstrak temulawak terhadap pertumbuhan daerah hambatan bakteri Aeromas hydrophila. Semakin tinggi konsentrasi ekstrak kunyit maupun ekstrak temulawak yang diberikan, memiliki kecenderungan meningkatkan daerah hambatan pertumbuhan bakteri Aeromas hydrophila.

Mitra program selanjutnya memperoleh materi pelatihan probiotik yang diterapkan melalui pakan ikan dan media air. Secara khusus mitra mendapatkan pemahaman dan ketrampilan terkait cara memilih probiotik yang baik, dosis pemberian baik melalui pakan ikan maupun melalui media air, dan cara perbanyakan probiotik berbasis pada bahan baku lokal.

\section{Pendampingan Manajemen Budidaya ikan di Kelompok Tani “Raja Oling”}

Kegiatan pendampingan tahap awal adalah pendampingan terkait penerapan cara budidaya ikan yang baik (CBIB), yang berpedoman pada petunjuk pelaksanaan sertifikasi cara budidaya ikan yang baik yang ditetapkan oleh kementerian kelautan dan perikanan. (DJPB, 2017).

Tahap kedua adalah pendampingan manajemen kualitas air, kegiatan ini menitik beratkan pada manajemen atau pengelolan kualitas air. Sebab mutu kualitas air baik merupakan salah satu faktor penentu keberhasilan kegiatan budidaya ikan lele. Tahapan dalam kegiatan ini meliputi yaitu:

1. Tahap 1.

Mitra memperoleh pengetahuan tentang proses penyaringan, dan pengendapan air yang berasal dari sumber air irigasi, hal ini penting dilakukan mengingat penggunaan sumber air tidak hanya untuk kegiatan budidaya perikanan akan tetapi untuk kegiatan pertanian, dan peternakan.

2. Tahap 2.
Mitra mendapatkan alih teknologi terkait cara pengukuran dan monitoring kualitas air meliputi suhu dengan mengunakan termometer raksa, $\mathrm{pH}$ dengan menggunakan kertas pH Lakmus, dan kecernihan atau kecerahan air, proses pengukuran dilakukan 2 kali pada pagi hari dan sore hari dua kali dalam semingggu. Tujuan untuk mengetahui mutu air sehingga layak untuk kegiatan budidaya.

3. Tahap 3.

Mitra mengetahui penerapan probiotik untuk menjaga agar kualitas air tetap layak selama kegiatan budidaya ikan.

4. Tahap 4.

Mitra memperoleh informasi fase perubahan warna air dan cara menumbuhan pakan alami agar mampu membatu mejaga mutu air budidaya ikan sekaligus sebagai penyedia pakan alami bagi ikan yang dibudidayakan.

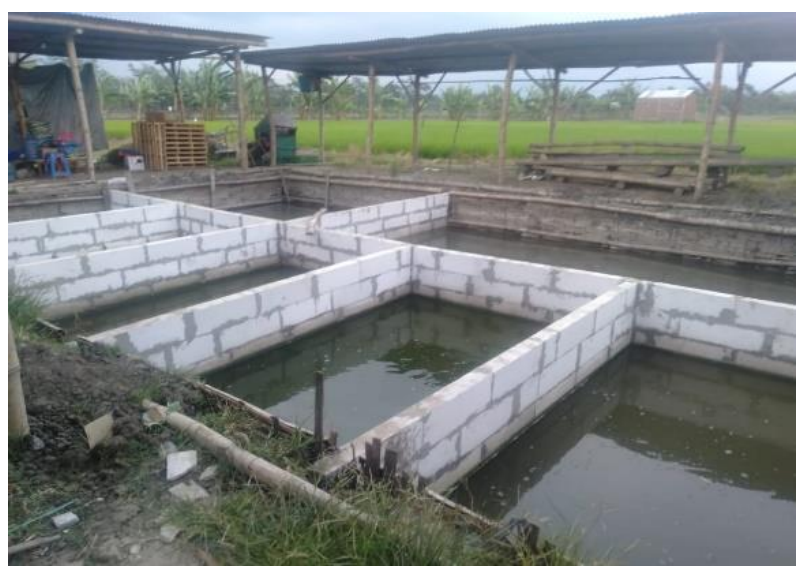

Gambar 2. Pendampingan Manajemen Budidaya Ikan yang Baik

Tahap selanjutnya adalah pendampingan cara perbanyakan probiotik. Tujuan dari pelaksanaan kegiatan ini adalah meningkatan ketrampilan dalam pembuatan perbanyakan probiotik, sehingga dapat mengurai biaya pembelian probiotik sekaligus produk perbanyakan nantinya dapat dipasarkan Berdasarkan hasil informasi dari mitra diketahui bahwa saat ini mitra menggunakan probiotik buatan pabrik dengan harga adalah Rp. 60,000,- /liter. Tingginya harga probiotik tentunya membebani biaya produksi ikan lele. Maka langkah yang diambil oleh tim pelaksana bersama mitra program adalah melakukan perbanyakan probiotik. Langkah awal adalah 
dengan melakukan identifikasi bahan baku pembuatan probiotik yang terdapat di wilayah mitra, adapun bahan baku yang tersedia di wilayah mitra adalah jahe merah, kunyit, buah mengkudu, susu sapi segar, dan tetes tebu atau molase, selanjutnya menyusun formulasi bahan perbanyakan probiotik, dan melakukan pengemasan. Menurut Sutarjo, dan Samsundari (2018) bahwa pencegahan hama, dan penyakit ikan dapat dilakukan melalui penggunaan probiotik ramah lingkungan, salah satunya melalui pemanfaatan tanaman herbal. Beberapa tanaman herbal yang dapat mencegah terjadinya serangan penyakit adalah tanaman kunyit, bawang putih, daun pepaya, dan buah mengkudu.

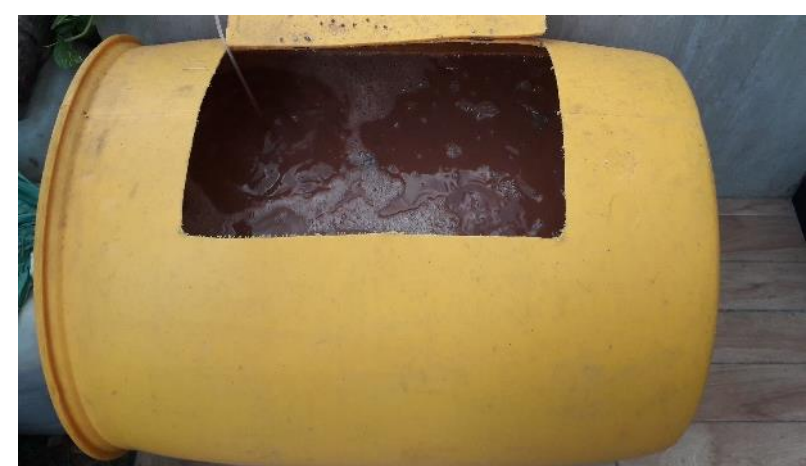

Gambar 3. Pendampingan Perbanyakan Probiotik Berbasis Bahan Baku Lokal

\section{Evaluasi Program Pengabdian di Kelompok Tani "Raja Oling".}

Dampak dari pelaksanaan pelatihan dan pendampingan pembuatan pakan ikan mandiri dan pengelolaan kualitas air pada kelompok Pembudidaya ikan Raja Oling mulai dapat dirasakan, kondisi tersebut terwujud karena adanya keterlibatan dan partisipasi aktif mitra dalam pelaksanaan program pengabdian, mulai dari banyaknya pertanyaan yang diajukan mitra pada saat pelaksanaan pelatihan hingga pendampingan khususnya berkaitan dengan cara budidaya ikan yang baik (CBIB), manajemen kualitas air, penggunaan serta proses perbanyakan probiotik. Mampu berdampak positif dalam peningkatan kapasitas produksi ikan air tawar kelompok.

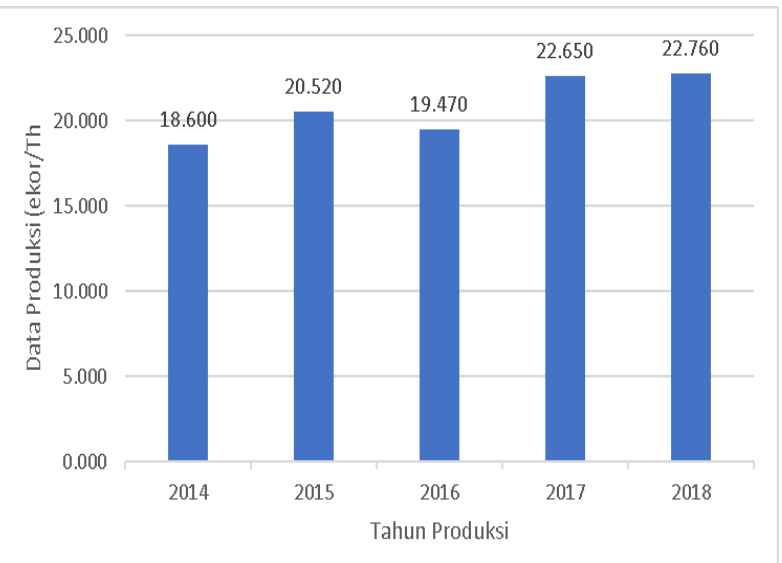

Gambar 4. Data Produksi Budidaya Ikan Air Tawar di Kelompok Raja Oling.

Data produksi ikan tersebut, menujukan terjadinya peningkatan produksi ikan pasca kegiatan pelatihan dan pengabdian. Kondisi tersebut, secara tidak langsung menunjukan bahwa peningkatan produksi ikan, diikuti dengan tingginya keterbukaan mitra terhadap alih teknologi dan penerapan teknologi terbaru sistem budidaya ikan dari sistem budidaya ikan secara tradisional menuju sistem budidaya ikan secara semi intensif dan intensif. Perubahan sistem budidaya ikan tersebut memberikan pengaruh besar pada para pembudidaya ikan Raja Oling. Sebab Mitra secara khusus, mitra memperoleh pendampingan secara penuh terkait penerapan Cara Budidaya Ikan yang Baik pada kegiatan usahanya sesuai ketentuan, dan cara manajemen atau pengelolaan kualitas air budidaya ikan yang baik. Sehingga dari pelaksanaan pelatihan dan pendampingan diharapkan mitra program dapat menginformasikan beberapa hal terkait budidaya ikan kepada kelompok-kelompok pembudidaya ikan lainnya di wilayah Kabupaten Malang, khususnya para pembudidaya ikan yang berada di Kecamatan Sukun.

\section{KESIMPULAN DAN SARAN}

\section{Kesimpulan}

1. Kegiatan pelatihan dan pendampingan program mampu meningkatkan pengetahuan dan ketrampilan Mitra program dalam penerapan Cara Budidaya Ikan yang Baik (CBIB), pengelolaan kualitas air pada kegiatan budidaya ikan secara berkelanutan, dan 
ketrampilan perbanyakan probiotik berbasis bahan baku lokal. hal ini dibuktikan dengan tingginya keterlibatan dan partisipasi aktif mitra dalam pelaksanaan program pengabdian.

2. Mitra mampu menerapan sistem pengelolan kualitas air secara berkelanjutan, sehingga target produksi budidaya dapat ditingkatkan.

3. Mitra program mampu memproduksi probiotik berbasis bahan baku lokal baik untuk memenuhi kebutuhan kelompok maupun masyarakat pembudidaya ikan umum dengan harga Rp. 60.000/kemasan.

\section{Saran}

Penerapan manajemen kualitas air dan perbanyakan probiotik secara berkelanjutkan sehingga dapat meningkatkan kapasitas produksi ikan dan menjaga kualitas lingkungan..

\section{DAFTAR PUSTAKA}

Direktorat Jenderal Perikanan Budidaya, 2017. Petunjuk Pelaksanaan Cara Budidaya Ikan yang Baik (CBIB). Kementrian Kelautan dan Perikanan Republik Indonesia. Jakarta.

Sutarjo G A, Samsundari S. 2018. Peningkatan Produksi Budidaya Ikan Air Tawar Melalui Penerapan Manajemen Kualitas Air Dan Pembuatan Pakan Ikan Mandiri Di Kelompok Pembudidaya Ikan "Sumber Rejeki" Dan "Cinta Alam" Kecamatan Bungatan Kabupaten Situbondo. Jurnal Dedikasi UMM. Vol. 15 Mei 2018. Malang

Sutarjo G A, Warkoyo. 2019. KKN PPM Pemberdayaan Masyarakat melalui Pengembangan dan Penguatan Kelompok Pembudidaya Ikan (Pokdakan) Air Tawar Desa Sepanjang Kecamatan Gondanglegi Kabupaten malang. Jurnal Dedikasi UMM. Vol 16, Mei 2019. Malang

Samsundari S. 2006. Penggunaan Bahan Obat Alami Terhadap Resistensi Bakteri Aeromonas hydrophilla yang Menyerang Ikan Mas (Cyprinus carpio). Jurnal Gamma UMM. Volume 2 No. 1 2006. Malang. 